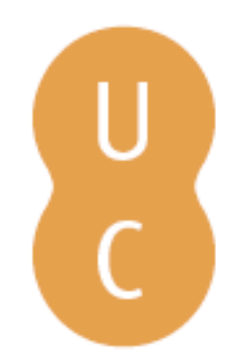

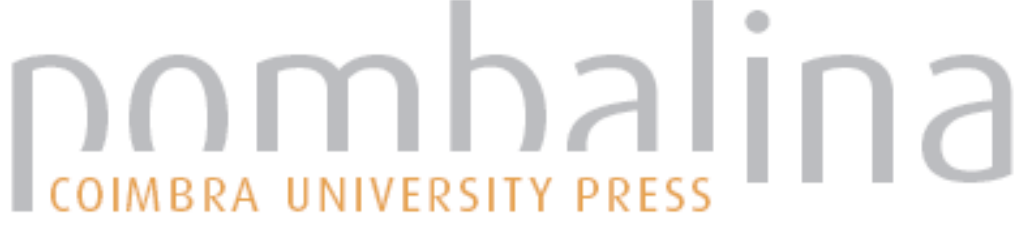

\section{Eryximachus and Diotima in Plato's Symposium}

\author{
Autor(es): Riegel, Nicholas
}

Publicado por: Imprensa da Universidade de Coimbra; Annablume

URL

persistente: URI:http://hdl.handle.net/10316.2/40877

DOI: $\quad$ DOI:https://doi.org/10.14195/978-989-26-1288-1_17

Accessed : $\quad$ 26-Apr-2023 07:08:45

A navegação consulta e descarregamento dos títulos inseridos nas Bibliotecas Digitais UC Digitalis, UC Pombalina e UC Impactum, pressupõem a aceitação plena e sem reservas dos Termos e Condições de Uso destas Bibliotecas Digitais, disponíveis em https://digitalis.uc.pt/pt-pt/termos.

Conforme exposto nos referidos Termos e Condições de Uso, o descarregamento de títulos de acesso restrito requer uma licença válida de autorização devendo o utilizador aceder ao(s) documento(s) a partir de um endereço de IP da instituição detentora da supramencionada licença.

Ao utilizador é apenas permitido o descarregamento para uso pessoal, pelo que o emprego do(s) título(s) descarregado(s) para outro fim, designadamente comercial, carece de autorização do respetivo autor ou editor da obra.

Na medida em que todas as obras da UC Digitalis se encontram protegidas pelo Código do Direito de Autor e Direitos Conexos e demais legislação aplicável, toda a cópia, parcial ou total, deste documento, nos casos em que é legalmente admitida, deverá conter ou fazer-se acompanhar por este aviso.

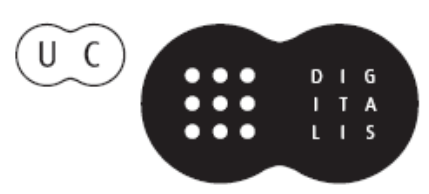




\section{Cosmópolis}

\section{mobilidades culturais às origens do pensamento antigo}

Gabriele Cornelli, Maria do Céu Fialho e Delfim Leão

\section{(coords.)}

IMPRENSA DA UNIVERSIDADE DE COIMBRA 


\title{
Eryximachus and Diotima in Plato's Symposium
}

\author{
Nicholas Riegel (nicholas.riegel@utoronto.ca) \\ Brasília University
}

\begin{abstract}
Авstract: I argue that in the Symposium Plato gives distinct indications that he wishes Eryximachus' speech to be compared with Diotima's. This helps reveal Plato's goals in constructing each speech, and supports a specific interpretation of the dialogue's structure.
\end{abstract}

Keywords: Plato, Symposium, Eryximachus, Diotima

\section{INTRODUCTION}

My research has focused on the structure of Plato's Symposium. In particular, I have been concerned with the significance of the speeches other than Socrates' in that dialogue. The problem is that, if Socrates' speech contains all that is philosophically interesting on the subject of love, then what is the point of the remaining six speeches? Taking my cue from the dialogue's many references to tragedy and comedy, my proposed solution is to divide the speeches into two tetralogies, mirroring the structure of the dramatic competitions at the City Dionysia in $5^{\text {th }}$ and $4^{\text {th }}$ century Athens. At this festival each tragic poet would compete by presenting a series of three tragedies followed by a satyr-play. So, in the Symposium the speeches of Phaedrus, Pausanias, and Eryximachus are serious, like tragedies, while Aristophanes' speech is humorous, like a satyr-play. And in the second tetralogy the speeches of Agathon, Socrates, and Diotima are serious, like tragedy, and Alcibiades' speech is explicitly called a satyr-play at $222 \mathrm{~d}^{1}$

The consequences of this analysis for the interpretation of the dialogue are at least two. The first is that each speech should in some way be especially related to its correlate in the other tetralogy. The second is that the first four speeches should constitute a coherent whole, which can be compared with the outlook of the second tetralogy. In this paper I will focus on Eryximachus' speech, to see the extent to which it satisfies these two criteria. I will first attempt to show how his speech has a special relation to Diotima's, and then I will explain how Eryximachus' speech functions within the first tetralogy. If we can show that his speech satisfies these two criteria, then this would lend support to the thesis that the Symposium should be divided into two tetralogies.

\footnotetext{
${ }^{1}$ This interpretation is more fully defended in Riegel 2015.
} 


\section{Eryximachus and Diotima}

At first glance, it may seem as though, of all the speeches, those of Eryximachus and Diotima have the least to do with one another. But we can begin to see how they are related with McPherran's observation that while Eryximachus is an iatros, or physician, Diotima is an iatromantes, or physician-diviner (McPherran 2006: 90). Of the fact that Eryximachus is a medical doctor, we are reminded throughout the dialogue ${ }^{2}$. About Diotima we are given little information. All we are told is that she is from Mantinea, and, by having the Athenians make a sacrifice, she effected a postponement of the plague for ten years (201d) ${ }^{3}$.

If Diotima is historical then the reference to Mantinea may be purely biographical. On the other hand, if she is fictional ${ }^{4}$ then we can ask about the significance of attributing that place of origin to her? One possibility is that Plato chose Mantinea because that was the site of a still recent disastrous battle for the Athenians during the Peloponnesian war ${ }^{5}$. Such an attribution may, then, have been to remind the gathering of the Athenian vulnerability and the difficult situation Athens was in. Alternatively, or perhaps also, as scholars have noticed, the name 'Mantinea' 6 is similar to words signifying prophecy, prophetic power, or divination?

${ }^{2}$ From the beginning at $176 \mathrm{~d}$, where he enlightens the gathering on the harmful effects

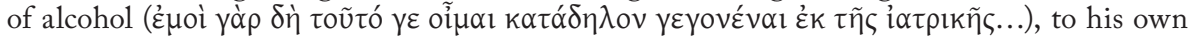
speech with its numerous references to his profession (186a, 186b, 186c, 186d, 186e, 187c, 187e 188c.) and his curing of Aristophanes' hiccoughs (185c-e, 189a.), to the latter part of the dialogue where Alcibiades tells Eryximachus, quoting the Iliad, "A doctor is worth many

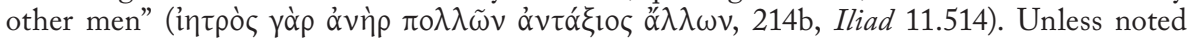
otherwise, all translations are my own. On Eryximachus cf. Nails 2002.

${ }^{3} \mathrm{We}$ are also told that she is wise in many things and that she taught Socrates about love. The attribution of wisdom to her is surprising given Socrates' position in the Apology. This raises issues about Socrates' own claims to wisdom and ignorance and the issue of what Diotima represents. However, for the purposes of this paper, we will focus on the other two data.

${ }^{4}$ There is no certain evidence of her outside the dialogue, and her references to arguments previously made at the banquet - not to mention her exposition of the Platonic Form Theory - support the view that she is a Platonic invention. Cf. Dover 1980: 137; Rowe 1998: 173; Nails 2002.

${ }^{5}$ Scholars generally agree that the dramatic date of the dialogue is 416 , and the battle of Mantinea took place in 418 , so that it would still have been fresh in the minds of the Athenians.

${ }^{6}$ Especially in the genitive form found in the text, mantinikes ( $\mu \alpha \nu \tau \imath v \imath k \tilde{\eta} \varsigma$ ).

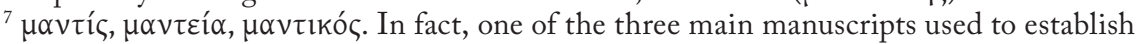
the text, codex Vindobonensis, has $\mu \alpha \nu \tau \imath \kappa \tilde{\eta} \varsigma$, signifying 'prophetic', instead of $\mu \alpha \nu \tau \imath v \imath \kappa \tilde{\eta} \varsigma$ at $201 \mathrm{~d} 2$. And the MS is consistent in this respect at 211d1-2. Thus if we follow the codex Vindobonensis, instead of saying that he heard a discourse about love from a woman from Mantinea, Socrates would say that he heard a speech about love from a prophetic woman - which, one could argue, would make more sense given what follows in the dialogue. But even if we reject this reading on the grounds that lectio difficilior potior, the similarity between 
The final piece of information we are given about Diotima is that, by having the Athenians make certain sacrifices, she effected a postponement of the plague for ten years. There are two significant aspects to this claim. The first is that she effected the postponement by having the Athenians perform certain sacrifices. This puts Diotima clearly in the camp of a religious worker of some sort. In fact, her connection with sacrifices explicitly associates her with Eryximachus' speech. Eryximachus is the first to address the topic of prophecy and its connection to sacrifices at length at $188 \mathrm{~b}-\mathrm{d}$. Though words signifying prophecy are used briefly by others thereafter ${ }^{8}$, no other speaker makes it an extended topic of his speech again until Diotima. Thus we see that there is probably a link between Eryximachus' speech and Diotima's on the subject of prophecy.

But what about the second part of the biographical information - namely that it was a plague which she postponed for ten years? Here there is an even stronger connection with Eryximachus, for there are only two instances of the

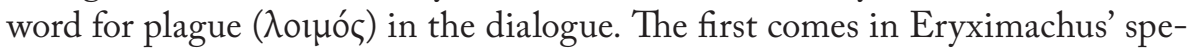
ech, where he speaks about what happens when the bad or hubristic sort of love becomes stronger in nature. The only other instance of the word comes at 201d, where Socrates introduces Diotima. Additionally, there are only seven instances of the word for sickness (vóøoৎ) in the dialogue. It will perhaps not be surprising that five of them occur in Eryximachus' speech. Less expected is that the only other occurrences are 1.) at 201d where Socrates introduces Diotima, and 2.) at 207b, where Diotima explains that all animals are sick when they desire to give birth.

The final point of similarity between the two speeches is that both Eryximachus and Diotima broaden the scope of love in their respective tetralogies. At 186a-b, Eryximachus expands love into a universal force. Likewise, but in a different way, Diotima expands the scope of love when she argues that all desire for goodness and happiness counts as love (205a, 206a). Thus, as she explains at $205 \mathrm{~d}$, those who pursue the good through making money, through gymnastics, or through philosophy are all in love. Love is a genus with species whose differentia apparently have to do with the means by which one seeks to attain the good and happiness. What we call love is actually that species of love which seeks to attain the good by giving birth in beauty.

Having discussed some of the similarities between Eryximachus and Diotima, let us turn to some the ways in which they are different. Eryximachus must be some sort of representative of the physicalist approach to medicine. Though, as we have seen, he acknowledges the efficacy of prophecy, his overwhelming

the name 'Mantinea' and the Greek words signifying prophetic power remain, and therefore could well be intentional.

${ }^{8}$ Aristophanes (192d), Agathon (197a), Socrates and Eryximachus (198a). 
concern is with the body. In his whole speech there is only one passing mention of the soul at 186a. All the rest of his discourse is concerned with the body and its elements. Diotima, on the other hand, is far more concerned with the soul than the body. While she acknowledges that some people are only pregnant in body (208e) and the ascent to the Higher Mysteries begins with an appreciation of physical beauty, the majority of her speech is concerned with those who are pregnant in soul, and with incorporeal beauty.

This contrast between Eryximachus and Diotima reflects the beginning of the Charmides, where Socrates criticizes Greek doctors for only concerning themselves with the body and not the soul. Charmides complains of a headache and Socrates tells him of a cure which he learned from a Thracian doctor of Zalmoxis. The Thracian doctor commends Greek doctors for taking a holistic approach to the body: they will not treat the eyes without also treating the head, and they will not treat the head without also treating the whole body. But he criticizes Greek medicine for stopping at this point, and not also continuing to treat the soul. This scene is reflected in the contrast between Eryximachus and Diotima. Eryximachus is the representative of Greek medicine, and as such a representative of the holistic approach to medicine. But the problem is that he does not treat the soul. Only with Diotima do we get a treatment of the human condition which begins with the soul.

\section{Eryximachus and the First Tetralogy}

Having compared Eryximachus' speech with Diotima's, let us now turn to the question of the relation of Eryximachus' speech to his own tetralogy. The first tetralogy is dominated by two related themes. The first is that, as Agathon explains, all the speakers of the first tetralogy fail to begin by analyzing love itself, and instead praise love for its effects. As I have argued elsewhere, ${ }^{9}$ their failure to begin by properly analyzing love itself leads to inherent difficulties with each speech. Thus, I will argue, the first way in which Eryximachus continues the theme of the first tetralogy is by failing to properly analyze love, and this leads ultimately to the deficiency of his own speech. The second way in which Eryximachus supports the theme of the first tetralogy is that he agrees with the others that love is a god. The identification of love as a god raises the question of the relation between tragedy and the first three speeches. By identifying love as more than he is, Eryximachus misses the mark, just as Aristophanes goes astray by identifying love as a purely human phenomenon.

To see how Eryximachus' failure to properly analyze love leads to the deficiency of his speech let us turn to the speech itself. The main thrust of his

\footnotetext{
${ }^{9}$ Riegel 2015.
} 
argument is to try to connect the good sort of love with the principle of harmony and concord. But a problem begins to appear in his interpretation of Heraclitus. He quotes Heraclitus as saying that the one, "differing from itself is in harmony with itself, just as the harmony of a bow or lyre" (187a). ${ }^{10}$ And he interprets this as supporting his view that love produces a harmony out of discord (187a). But it has been noticed that here Eryximachus seems to miss Heraclitus' point. $\mathrm{He}$ does not mean that the discord between opposites disappears with the institution of harmony, as Eryximachus thinks; rather, it is out of the strife of the opposing forces that harmony arises. ${ }^{11}$ This misinterpretation hints at a problem with Eryximachus' account. He speaks as though love conquers all the discord in the universe, but according to Heraclitus discord and opposition are conditions of harmony. The introduction of Heraclitus reminds readers that at best the good kind of love has a temporary victory in the universe. As Eryximachus must know, even the healthiest body eventually succumbs to the forces of decay and discord. And this is where his account breaks down, for love cannot be a desire merely for temporary happiness. As we will learn from the second tetralogy love must be for eternal happiness, and it is this element of our mortality which Exyximachus fails to address. Like all the other members of the first tetralogy, Eryximachus' failure to begin by correctly analyzing love, leads to a deficiency in his speech. In this way he is consistent with a dominant theme of the first tetralogy.

The second way in which Eryximachus supports a dominant theme is that he accepts the assumption that love is a god. The first tetralogy errs by treating love as both more and less than it is. In the first three speeches - which constitute the tragic trilogy of the first tetralogy - love is treated as a god. In Aristophanes' speech love is treated as a purely human phenomenon. And I believe that Plato uses the dramatic genres of tragedy and comedy to emphasize this misunderstanding of love. As Clay 1983 explains, tragedy and comedy are distinguished by being concerned with 'the high' and 'the low'. Tragedy often takes as its subject stories of gods and heroes; it is concerned with what we might call 'noble' subject matter. Comedy, on the other hand, deals with the common, the lowborn, the everyday. ${ }^{12}$ Thus by using the dramatic genres of tragedy and

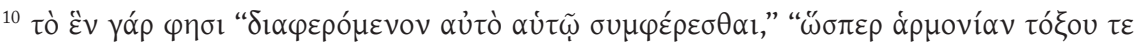

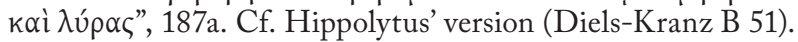

11 "Heraclitus seems to mean that the attunement of the lyre is achieved by the opposing tensions of string and instrument; if so, Eryximachus misses the point completely" (Nehamas \& Woodruff 1989: 21 n. 24).

12 "For Plato, tragedy centered on the high and serious, comedy on the low and laughable. Tragedy produced in the theater of Dionysos fear, grief, pity; and comedy produced laughter through arousing the ignorant emotion of phthonos. Both are defined by the high or what is considered high in human experience, and the low or what is considered low" (Clay 1983: 194). 
comedy in the first tetralogy, Plato may be emphasizing that the first three speakers treat love as more than it is; while Aristophanes, by presenting a comedy treats love as less than it is. Thus both by failing to begin by properly analyzing love itself and by treating love as more than it is, Eryximachus supports the theme of the first tetralogy.

\section{Conclusion}

The paper began by proposing a bi-tetralogical interpretation of the structure of the Symposium, mirroring the structure of the dramatic competitions at the City Dionysia. If this analysis is correct, then we would expect each speech to have two characteristics. First, each speech should be specially related to its correlate in the other tetralogy. And second, each speech should support the dominant themes of its own tetralogy. And it has been argued that Eryximachus' speech satisfies these two criteria. With respect to the first criterion, Eryximachus and Diotima are both characterized as kinds of doctors. Only in their speeches are words for sickness and plague used. Second, only these two speakers address the topic of prophecy at length, and in fact Eryximachus' mentioning of prophecy looks forward to Diotima. And finally, each expands the scope of their investigation. Eryximachus turns Love into a universal force, while Diotima explains that all desire for the good constitutes the genus of love.

With respect the second criteria, Eryximachus supports the theme of the first tetralogy in two ways. First, by failing to begin by properly analyzing love, his speech - like all the other speeches in the first tetralogy - is ultimately deficient. The reason why it is deficient becomes clear only in Diotima's speech: we do not just want the good; we want it forever. Secondly, his speech agrees with the previous speakers in assuming that love is a god. In assuming that love is a god, Eryximachus misses the mark by making love more than it is. By failing to begin by properly analyzing love, all the speeches in the first tetralogy become deficient in treating love is either more or less than it is. The fact that Eryximachus' speech satisfies these two criteria supports the thesis that the Symposium reflects a bi-tetralogical structure. 


\section{Works Cited}

Clay, D. (1983), “The Tragic and Comic Poet of the Symposium”, in J. P. Anton \& A. Preus (edd.), Essays in Ancinet Greek Philosophy, Vol. II. Albany.

Dover, K. J. (1980), Plato: Symposium. Cambridge.

McPherran, M. L. (2006), "Medicine, Magic, and Religion in Plato's Symposium' 71-95”, in J. Lesher, D. Nails \& F. Sheffield (edd.), Plato's Symposium: Issues in Interpretation and Reception. Cambridge.

Nails, D. (2002), The People of Plato: A Prosopography of Plato and Other Socratics. Indianapolis/Cambridge.

Riegel, N. (2015) “The City Dionysia and the Structure of Plato's Symposium” Ancient Philosophy 35(2).'

Rowe, C. J. (1998), Plato: Symposium. Oxford. 